Cad. Est. Ling., Campinas, 46(2):253-267, Jul./Dez. 2004

\title{
O MST NO DISCURSO JORNALÍSTICO: CONFRONTO DE POSIÇÕES DE FORMAÇÕES DISCURSIVAS
}

\author{
LEDA VERDIANI TFOUNI \\ LUCÍLIA MARIA SOUSA ROMÃO \\ (USP) \\ "Quem manipula o poder, manipula o esquecimento." \\ Le Goff
}

\begin{abstract}
RESUMO Esse artigo pretende, à luz da Análise do Discurso de filiação francesa, analisar o confronto de duas formações discursivas em relação ao Movimento dos Trabalhadores Rurais Sem Terra (MST), materializado na mídia impressa. As noções de ideologia, sujeito, memória e sentido foram mobilizadas para esboçar o gesto de interpretação, enfatizando o efeito do político sobre a linguaem.

PALAVRAS-CHAVE Sujeito, sentido, memória, ideologia, mídia, Movimento dos Trabalhadores Rurais Sem Terra.
\end{abstract}

\section{INTRODUÇÃO}

Sendo a memória discursiva constitutiva do sentido, há sempre várias vozes, historicamente já constituídas, que voltam à tona, ressignificando certa formação discursiva (FD). A amarração do discurso do sujeito com o discurso do outro indica a ideologia interpelando-o; tem-se aí uma dependência / identificação / associação a uma FD já dita. O sentido respira sempre atrelado ao interdiscurso. Nesse artigo, buscamos compreender como a ideologia produz o efeito de evidência e como a memória é permanentemente reclamada nos relatos da mídia, a partir da instalação de sentidos de repetição e deslocamentos. Sendo assim, analisaremos duas formações discursivas em jogo de enfrentamento sobre o mesmo tema, o MST, e apontaremos as marcas e indícios que, na ordem da língua, atualizam a ordem da história.

\section{II- SOBRE O DISCURSO JORNALÍSTICO}

A rota teórica da Análise do Discurso (AD) de filiação francesa servirá de base para respondermos às seguintes questões: como o discurso jornalístico apresenta o sem-terra? É a mídia capaz de naturalizar um sentido sobre o MST? Qual a relação entre o discurso 
TFOUNI E ROMÃO - O MST no discurso jornalístico:

jornalístico e a FD dominante? Existe apenas uma formação discursiva disponível para o discurso jornalístico, ou há mais de uma, inclusive antagônicas? Como os dizeres já significados nas lutas camponesas voltam a integrar o discurso jornalístico? Para iniciar essa discussão, apresentamos uma citação de Arbex (2000, p.45):

\begin{abstract}
"Questão de consciência"
Episódio 1: O jornalista Luís Costa Pinto, da revista Época, afirma, em Porto Alegre, em novembro, que o MST é dirigido por um 'núcleo duro' que, na verdade, não quer a reforma agrária, mas sim instrumentaliza o movimento para atingir os seus próprios fins. Episódio 2: O jornalista Marcos Emílio Gomes faz uma 'entrevista' com Raul Jungman, ministro do Desenvolvimento Agrário, para a revista Veja (edição de 15 de novembro), que, a partir do título ('O MST se perdeu'), faria inveja a qualquer diário oficial ou revista 'chapa branca' no pior estilo. Episódio 3: O jornalista Josias de Souza, da Folha de São Paulo, 'denuncia', em maio, a cobrança de 'pedágios' pelo MST, prática posteriormente qualificada como 'mafiosa' em editorial do próprio jornal, em resposta a uma denúncia comprovada e admitida de que Josias, para fazer sua 'reportagem', utilizou recursos e orientação do INCRA.

Esses episódios são muito ilustrativos, não por revelar aquilo que, na verdade, já se sabe-que a mídia brasileira é extremamente hostil aos movimentos populares em geral, e ao MST em particular-, mas por evidenciar o papel de grande relevância ocupado pelos jornalistas na guerra contra as organizações dos pobres no país. Não são mais os generais da ditadura, nem os seus agentes, nem sequem são os donos das empresas jornalísticas que acusam as organizações populares de prática de corrupção, de manobrar os 'inocentes úteis' com fins escusos, de serem a sucursal de Satanás na Terra. São os próprios jornalistas que metem a mão na massa e 'mostram serviço' Em geral, eles são eficientes, pois eram 'de esquerda' quando fizeram a universidadecomo muitos, aliás adoram propagar -, e conhecem bem os argumentos que tocam a sensibilidade da classe média."
\end{abstract}

O trecho citado expõe, a partir de uma posição-sujeito ocupada pelo autor que, como veremos, é de resistência à FD dominante, um confronto no discurso jornalístico, que marca a atualidade brasileira. Ainda que pensando o sujeito empiricamente, o autor tenta na sequência definir o que seria uma tendência no jornalismo em tempos de globalização:

\footnotetext{
"As megacorporações, capacitadas tecnologica- mente a unificar a imagem do mundo por meio de satélites e canais de fibra óptica, passaram a apresentar o próprio mundo (...) como se fosse um grande show, um espetáculo pirotécnico destinado a comprovar, incessantemente, que 'sociedade' e 'mercado' são, sempre e necessariamente, a mesma coisa (...) Essas midiáticas se tornaram essenciais ao funcionamento do capitalismo contemporâneo. Através de suas narrativas e explicações sobre os fatos do mundo, elas criam lógica e coerência onde não existem lógica e coerência alguma.."
}

As críticas, apresentadas por Arbex (2000), serão aqui enfocadas sob o ponto de vista das noções de sujeito, ideologia e formação discursiva (FD), privilegiando na análise a questão do lugar social ocupado pelo sujeito do discurso jornalístico. Dito de outra maneira, interessa-nos averiguar que posição diante do poder instituído, quais sítios de significação e quais efeitos de ilusão da objetividade tais dizeres instalam e produzem.

Certo que o discurso jornalístico organiza direções de leitura, fazendo circular alguns sentidos e desviando outros tantos, indesejáveis. Ao enunciar, o sujeito recorta na rede de filiações de sentidos (o interdiscurso, que é constituído historicamente) os dizeres que melhor contemplam a noção de "verdade segura", tão proclamada pelos órgãos de imprensa. Os manuais de redação e estilo indiciam o mecanismo de padronização e produção da 
notícia em série, dentro de uma cadeia de recortes, seleções e, assim, enquadramentos políticos (Romão, 2002; Voese, 1998; Mariani, 1998; Furtado, 2000).

Sob o pretenso manto da tríade objetividade-neutralidade-distanciamento dos fatos, o sujeito do discurso jornalístico textualiza a ilusão do didatismo de informar e comunicar a novidade de modo que ela apareça nomeada como a própria realidade. Dizemos ilusão, porque para a $\mathrm{AD}$ não há um sentido já fixado, prévio, antecipado no dizer; desta forma a noção de texto como comunicação (idéia e conteúdo transparentes) é descartada por princípio. Também esse não foi o manequim escolhido por Mariani (1998). Ela retirou a maquilagem discursiva que a imprensa havia construído sobre o PCB ao longo de quase setenta anos. Citamos um fragmento de seu trabalho, visto que, ao lado de ser sobre o discurso jornalístico, aplica-se também ao MST:

\begin{abstract}
"Os jornais lidam com o relato de eventos inesperados, possíveis elou previsíveis. Em seu funcionamento, o discurso jornalístico insere o inesperado (aquilo para o que ainda não há memória) ou possível / previsível (ou seja, fatos para os quais se pode dizer algo porque guardam semelhanças com eventos ocorridos anteriormente) em uma ordem, ou seja, organizando filiações de sentidos possíveis para o acontecimento (...) Para tanto, os jornais nomeiam, produzem explicações, enfim 'digerem' para os leitores aquilo sobre o que se fala. Esse processo de encadeamento cria a ilusão de uma relação significativa entre causas e consequiências para os fatos ocorridos. Encontra-se nesse funcionamento jornalístico um dos aspectos de convencimento que envolve os leitores." (op.cit., p.58/59)
\end{abstract}

Nessa tentativa de espelhar/explicar o mundo, o discurso jornalístico faz uso de uma retórica que tem por objetivo fazer a informação parecer segura, confiável e fiel à realidade. A ideologia se incumbe de fazer parecer que esse é o único modo de dizer. Trata-se de uma couraça ilusória de que a verdade é absoluta, única e tem um só dono. Assim também define Silva (1988, p.172):

"O dizer da imprensa deve dizer a 'verdade', correspondendo ao desejo de conhecimento do sujeito leitor: a imprensa se situa a partir de uma imagem de credibilidade perante a sociedade, perante seu público."

Lançando mão de tabelas, gráficos, mapas, estatísticas, quadros explicativos, pesquisas inéditas, fotografia e fotomontagens, a tônica do discurso jornalístico é generalizar e fixar um dizer como irrefutável. Certeau (1999, p.286/287) coloca como a mídia promove o que ele chama de "instituição do real":

\footnotetext{
"Só se vêem por todo lado notícias, informações, estatísticas e sondagens. Jamais houve uma história que tivesse falado ou mostrado tanto. Jamais, com efeito, os ministros dos deuses os fizeram falar de uma maneira tão contínua, tão pormenorizada e tão injuntiva como o fazem hoje os produtores de revelações e regras em nome da atualidade. Os relatos do-que-está-acontecendo constituem a nossa ortodoxia. Os debates de números são as nossas guerras teológicas. Os combatentes não carregam mais as armas de idéias ofensivas ou defensivas. Avançam camuflados em fatos, em dados e acontecimentos. Apresentam-se como mensageiros de um real. Sua atitude assume a cor do terreno econômico e social. Quando avançam, o próprio terreno parece também avançar. Mas, de fato, eles o fabricam, simulam-no, usam-no como máscara, atribuem a si o crédito dele, criam assim a cena da sua lei."
}

A repetição do relato jornalístico como retrato fiel da realidade cria o efeito de universalização como a apresentar um script a ser encenado sem nenhum comentário do 
TFOUNI E ROMÃO - O MST no discurso jornalístico:

ator. Há uma virtualidade na confecção de uma imagem e uma representação vendida como universal. Sendo assim, o que é recorte, angulação e seleção circula apoiado pelo efeito de evidência como se todos os sentidos pudessem ser esgotados em determinada reportagem; Voese $(1998$, p.23) tateou de perto a história do jornalismo, ocupando-se especialmente da imagem de neutralidade e objetividade, apregoada pela imprensa, tendo a informação como mercadoria à venda:

\begin{abstract}
"Essa insistência em criar uma imagem de neutralidade em relação ao exercício do poder é um processo em que se busca como que cristalizar um enunciado mais ou menos parecido com a 'imprensa informa com imparcialidade'. Torna-se instigante, especialmente para uma AD que se propõe a incluir as determinações sociais no seu objeto de análise, perguntar por que uma prática social tenta criar essa imagem, mesmo porque outras práticas também se valem do mesmo processo para consolidar-se dentro da formação social tal como se verifica, por exemplo, no Direito ("Todos são iguais perante a lei.", "A justiça é cega."), na Política ("Estar a serviço do povo"), no Exército ("Entrar na guerra para defender a democracia", "Se queres a paz, prepara-te para a guerra."), na Educação ("Preparar o indivíduo para a vida.") etc.

Essas imagens que se cristalizam em torno das práticas sociais- e que podem ser desconstruídas muitas vezes até com certa facilidade- são fruto de um processo que deve ser visto como estratégia discursiva não só de consolidação do grupo, mas também de mascaramento de determinados objetivos e interesses que se constituem em função dos conflitos sociais."
\end{abstract}

Nessa citação, fica aparente como os genéricos e as verdades fabricados pela mídia fazem circular o efeito de verdade inquestionável. Assim, a estratégia do discurso jornalístico cristaliza um dizer, através de recursos como a apresentação de textos, reportagens, matérias sem autor explícito. A ausência de um nome, de um responsável pelo dito, tem impacto na relação imaginária com o leitor: a noção de credibilidade não pode se relacionar a uma mera opinião pessoal, partícula de um mundinho reduzido e digno de apenas uma voz. O discurso jornalístico merece crédito, justamente porque sua voz genérica sinaliza dizeres que parecem tão verdadeiros, que se tornam Lei. E Lei não comporta opinião, interpretação nem crítica; deve ser aceita e maximizada na sua impessoalidade. Guimarães (2002, p.26) faz um estudo interessante dos genéricos, explorando os ditos populares. Emprestamos do autor um fragmento que se aplica ao discurso jornalístico:

\footnotetext{
"Quando apresentamos uma afirmação sem qualquer modalização como 'Todas as pessoas morrem', o enunciador, ao se apresentar como quem diz algo verdadeiro (...) O que esta representação significa? Significa a identificação do lugar do enunciador com o lugar do universal. Ou seja, um lugar de dizer em que se apresenta como não sendo social, como estando fora da história, ou melhor, acima dela. Este lugar representa um lugar de enunciação como sendo o lugar do qual se diz sobre o mundo."
}

Na mesma esteira argumentativa, Tfouni (2002), antepõe dois tipos de genéricos: um genérico que serve a um discurso narrativizante, e está aberto a múltiplas interpretações, como, por exemplo, "Cada macaco no seu galho", e outro genérico, que é aquele do discurso científico, o qual não admite deriva de sentidos, por funcionar na direção de criar uma aparente verdade universal, como por exemplo: "Todo sal dissolve no líquido". As posições de sujeito-intérprete, que são alocadas por um e outro discurso, são antagônicas: a interpretação do genérico narrativizante é aberta a diferentes visões do mundo e a diferentes experiências do sujeito; já o genérico do discurso científico fecha-se em uma única 
Cadernos de Estudos Lingüísticos 46(2) - Jul./Dez. 2004

possibilidade de interpretação: aquela que corresponde a uma "verdade", em geral, demonstrada empiricamente.Iremos mostrar, aqui, que discurso jornalístico e discurso científico utilizam as mesmas ferramentas lingüísticas, para obter resultados semelhantes de interpretação: o de estabelecer uma verdade inquestionável, irrefutável, fazendo parecer que os "fatos" só podem ser vistos por aquela ótica, e apagando, desta maneira, posições interpretativas alternativas e antagônicas.

\section{III- SOBRE A MEMÓRIA E A FORMAÇÃO DISCURSIVA}

Essas questões nos remetem a dois conceitos importantes para a AD: a memória e a formação discursiva. Sobre o primeiro, marcamos que existe um interdiscurso (Pêcheux, 1975) que sustenta os processos de significação e que somente o retorno ao arquivo garante o gesto de leitura e interpretação. Ou seja, há uma memória do dizer, pontuada pela inscrição do uso dos significantes em outras conjunturas sócio-históricas; então, as palavras carregam, em seu bojo, as marcas desses usos sociais. Dito assim, a mídia se coloca na esteira dessa memória discursiva, jogando com os sentidos do já-lá, que são reconfigurados e atualizados permanentemente. Sobre o conceito de formação discursiva, tomamos Pêcheux (1975: 160) que o define do seguinte modo:

"aquilo que numa formação ideológica dada, isto é a partir de uma posição dada numa conjuntura dada, determinada pelo estado da luta de classes determina o que pode e deve ser dito (articulado sob a forma de uma arenga, de um sermão, de um panfleto, de uma exposição, de um programa, etc)"

Analisaremos a seguir uma matéria publicada pela Revista Veja, em 10 de maio de 2000, cujo título é "Sem terra e sem lei", assinada por Eduardo Oinegue. Observamos que uma síntese da análise apresentada a seguir foi publicada em Romão \& Tfouni (2002). Na capa da publicação, o fundo verde da bandeira brasileira contrasta com a bandeira tremulante do MST, pulsando o efeito de sentido: perigo vermelho à vista, ameaça extermina a paz nacional. Só no uso das cores, já existe certa intencionalidade: o verde da soberania nacional, da riqueza e do patrimônio naturais mais ufanistas do país em contraposição com o vermelho do socialismo, o vermelho que evoca o comunismo, ameaça do passado que retorna com nova roupagem.

O título da matéria anuncia: "A tática da baderna - o MST usa do pretexto da reforma agrária para pregar a revolução socialista”. No intradiscurso, o sujeito privilegia uma seqüência factual das ações do MST, no estilo de flashes rápidos e, depois, formula algumas considerações téoricas sobre a reforma agrária no país. Tem-se, assim, os seguintes recortes, todos predicando as ações do MST:

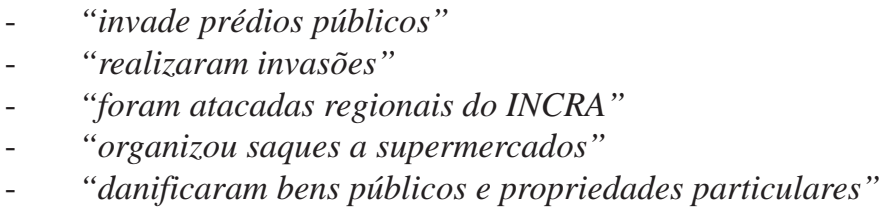


TFOUNI E ROMÃO - O MST no discurso jornalístico:

- "houve muita confusão (...) e uma tragédia”

- " "invadiram repartições públicas impedindo-as de funcionar”

- "mantiveram servidores em cárcere privado"

- " " a tropa de choque fez a desocupação e prendeu quinze manifestantes"

- " "o governo mandou oitocentos policiais conter o avanço de quarenta ônibus que levavam os sem-terra”

Tais fragmentos na ossadura da língua já seriam suficientes para indiciar que tal discurso remete a uma posição de classe, conformada ideologicamente por um sujeito que se sente ameaçado quando o tema é reforma agrária, e MST, portanto. Nesse momento, é importante retomar os dizeres que já foram construídos pela historicidade. A tentativa de associar os sem-terra a baderneiros, organização criminosa, impecilho para a democracia e a paz (re)edita sentidos que remontam à colonização, aos quilombos e ao levante de Ibicaba, às lutas messiânicas - Canudos, Contestado e Ligas Camponesas em especial. (Tfouni e Romão, 2003). Há uma negociação com a mesma FD oficial, que construiu uma imagem de perigo e uma representação de bandidagem e, no plano ideológico, encaminhou o julgamento final: extermínio e prisão dos que enunciam de um outro lugar social. É importante dizer que tais FDs conflituosas são determinadas pela dinâmica e tensa luta de classes, pelos interesses de grupos colocados socialmente em posição de dominação e subordinação. Daí o discurso de luta pela terra receber o nome de discurso do conflito. Chocam-se dois dizeres, constitui-se o lítigio discursivo.

A FD, na qual a revista Veja se inscreve, é uma agulhada no corpo discursivo do MST e regulariza o papel da memória através das paráfrases, do efeito metafórico, de substituições semelhantes, como a afirmar: antes, eles matavam o gado; agora, "se apropriam dos bens dos fazendeiros". Antes, promoviam a desordem no campo, hoje “destroem bens públicos ou dos fazendeiros". Antes, fundavam povoados e redutos fanáticos; hoje, formam "quadrilhas e praticam crimes" de "invasão, lesão corporal, cárcere privado, corrupção de menores”. O movimento discursivo é o mesmo, guardadas as variações históricas e as particularidades da conjuntura sócio-histórica. No movimento desse jogo de cadeias parafrásticas, Achard (1999, p.16) lança luz sobre a tentativa de regularizar um sentido:

\footnotetext{
"é engendrando, a partir do atestado discursivo, paráfrases, a considerar como derivações de possíveis em relação ao dado, que a regularização estrutura a ocorrência e seus segmentos, situandoos dentro de séries. O que desempenha nessa hipótese o papel da memória discursiva são as valorizações diferentes, em termos por exemplo de familiaridade ou de ligações a situações, atribuídas às paráfrases, que entretêm então, graças ao processo controlado de derivação, relações reguladas com o atestado".
}

A paráfrase, conforme já definimos anteriormente, alavanca a cristalização de um sentido único, o mesmo volta a ser apresentado de forma a fixar o já-dito. Ao narrar as ações do MST, o sujeito do discurso, que produz esse texto da revista Veja, é interpelado pela ideologia que promove o sentido ilegal, criminoso e ameaçador quando narra a ação dos sem-terra e do líder. Em todas as substituições a seguir, prevalece um dizer condenatório e humilhante dos feitos do Movimento. 


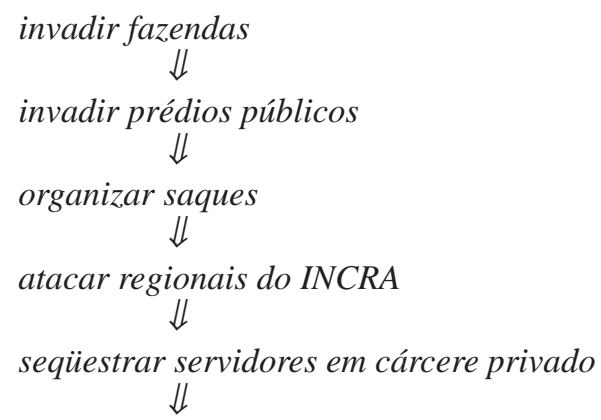

avançar promovendo a tragédia

O funcionamento discursivo dessa narração jornalística silencia qualquer ação positiva /construtiva que o MST tenha realizado ao longo dos seus vinte anos de existência. Assim, ao invés de a interpretação ficar em aberto para possíveis alternativas e inclusive derivas, como seria de se esperar, visto que se trata de um relato, portanto, uma narrativa, temos aí que apenas um único sentido é eleito: satanizar os feitos dos sem-terra, vociferar contra o pobre organizado em forma de mobilização política. Isso cimenta uma argamassa, chamada FD dominante, que circula na maioria dos jornais e revistas de circulação nacional, ainda que, em alguns momentos, outros sentidos sejam produzidos à revelia do sujeito, construindo ambigüidades, equívocos, deslizamentos de sentido ou pontos de deriva.

Uma imagem acompanhou a matéria acima. Trata-se de uma foto-montagem de João Pedro Stedile, líder do Movimento, foto esta que indicia a mesma FD. A começar pela imagem, há uma série de elementos capazes de criar o efeito de sentido quadrilha-violência-

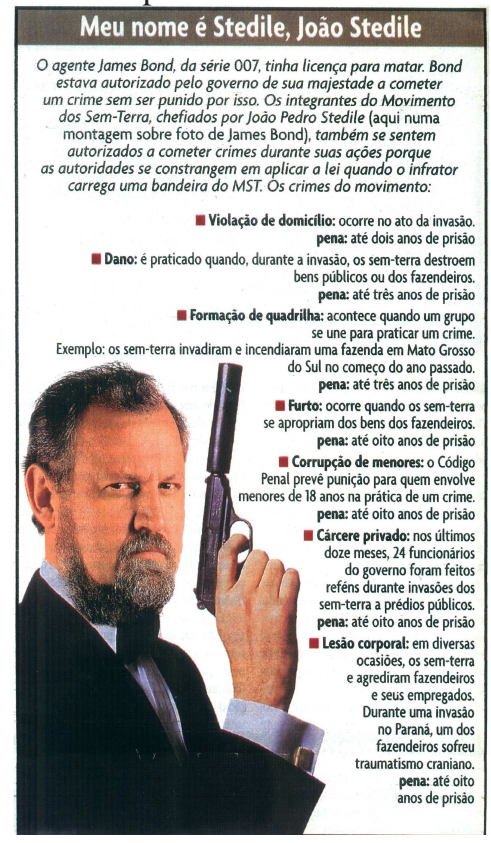


TFOUNI E ROMÃO - O MST no discurso jornalístico:

perigo. A roupa social (smoking e abotoaduras) indica a posição elitista como a insinuar o líder-vida-mansa desvinculado da base popular, desligado de outro interesse que não seja a sua arma, a sua expressão dura/agressiva e o seu status. Na montagem do picadeiro simbólico, há um enquadramento condenatório da pessoa Stedile através da roupa, da arma e da expressão facial. Ele forma a cúpula do poder transgressor, a elite da malandragem, o alto escalão do crime organizado: esses são os efeitos de sentido construídos a partir desse discurso. Isso significa na/pela fotomontagem, o dado, cuja materialidade simbólica historiciza sentidos, ainda que sob a representação visual, ainda que de modo implícito.

É correto afirmar que o valor do recurso não-verbal, apresentado pela Revista Veja, faz parte do jogo descrito acima. Mais do que um elemento acidental plantado nas páginas da uma revista, mais do que um valor estético, a fotografia promove uma certa maneira de perceber e discursivizar o MST, de formatar a opinião pública em prol de sua condenação. A imagem ganha estatuto de texto, quando observamos a FD na qual a revista se inscreve.

Olhar exclusivamente para a foto é perder a grande oportunidade de des-construir a materialidade lingüística, cujo primeiro indício aparece em forma de paráfrase da Veja: "Meu nome é Stedile, João Stedile". Logo no início, o discurso regurgita uma rememoração da figura emprestada do cinema americano. James Bond renegocia os efeitos de sentido postos pela imagem de justiceiro, violento, malvado e criminoso. Em segundo plano, outro eco se faz presente, estabelecendo um contraponto de ridicularização com o herói invencível representado por Bond: "Meu nome é Enéas", mote utilizado por candidato a eleições cuja posição sujeito predominante é considerada incendiária e de extrema direita.

De acordo com a AD, o dizer significa pelo dispositivo da memória. Como numa série matemática, o interdiscurso estabelece uma relação de repetição estabilizada, porém passível de quebra e falha. O ritual da estabilização pode ser sinônimo de permanência, mas é o espaço possível da emergência do outro, diferente. Mariani (1998, p.38) faz essa topografia da memória, que une passado, presente e futuro discursivamente:

\footnotetext{
"A memória pode ser entendida como a reatualização de acontecimentos e práticas passadas em um momento presente, sob diferentes modos de textualização (...) na história de uma formação ou grupo social. $O$ recordar possibilitado pela memória também se concretiza no movimento do presente em direção ao devir, engendrando assim uma espécie de 'memória de futuro' tão imaginária e idealizada quanto a museificação do passado em determinadas circunstâncias.

Retomando o que foi dito, podemos afirmar que pensar discursivamente a memória é analisar as formas conflituosas de inscrição da historicidade nos processos de significação da linguagem."
}

Observemos o seguinte recorte da matéria da Veja: "O Movimento dos Sem-Terra, chefiado por João Pedro Stedile também se sente autorizado a cometer crimes durante suas ações". Essa seqüência identifica a ação coletiva na direção da criminalização da organização. O chefe, o crime e a autorização da liderança funcionam de modo a trucidar a imagem da legalidade e da democracia que o MST vive no seu interior. Fica parecendo que o líder dita ordens e os militantes seguem-no cegamente, sob a ameaça de uma arma. Ou ainda que se trata de um personagem politicamente "menor" (como Enéas), porém " perigoso", pelo apelo popular de suas idéias e pelo modo como trata os filiados a seu partido, o PRONA, de maneira tirânica. No jogo do que Pêcheux (1999, p.56) define como a memória: 
“... [a memória] não poderia ser concebida como uma esfera plena, cujas bordas seriam transcedentais históricas e cujo conteúdo seria um sentido homogêneo, acumulado ao modo de um reservatório: é necessariamente um espaço móvel de divisões, de disjunções, de deslocamentos e de retomadas, de conflitos de regularização... Um espaço de desdobramentos, réplicas, polêmicas e contra-discursos."

Entra em movimento uma operação discursiva para didatizar o sentido da gravidade e perigo do "elemento criminoso". Periculosidade aparece como efeito de sentido, que justifica a instalação de uma ficha policial e apresenta, nos itens lexicais abaixo, a mesma desqualificação, que já foi atribuída a outras lideranças populares.

Neste momento, apontamos que há uma regularidade nos relatos da mídia, construída pela instância ideológica dos sentidos dominantes, que promove as ações nocivas dos militantes desses movimentos todos sobre a posse da terra (Canudos, Contestado, etc.). As acusações de "invadir matar o gado, incendiar a casa-sede da fazenda, arrebentar a cerca", já aparecem colocadas pela FD dominante contra os conselheiristas de Canudos (cf, Tfouni \& Romão, 2003). O discurso da Veja recupera tais sentidos e, acrescentando os "novos feitos" do MST, - "destruir bens públicos, agredir fazendeiros, fazer reféns inocentes, se apropriar de algo alheio, roubar" - virtualiza os novos satãs da pósmodernidade, verdadeiros minotauros devoradores da civilização democrática e neoliberal.

Em sintonia com a mesma região do interdiscurso colocada acima, recuperamos aqui o fragmento do Jornal O Estado de S.Paulo, de 11 de outubro de 1997. O Informe JB, cujo autor é Walter Fontoura, apresenta o seguinte "relato":

\footnotetext{
"Como uma societas celeris, a direção do MST está reunida clandestinamente há três dias, em São Paulo, deliberando em segredo sobre seus próximos passos. Depois das últimas peripécias, a direção dividiu o País em cinco regiões- Pernambuco, Mato Grosso do Sul, Paraná e Pará-e promoveu reuniões regionais para 'tirar posições' a debater no encontro secreto de São Paulo. $O$ fracasso do último round de negociações com o Governo parece ter desorientado as lideranças do movimento (...) Há notícias de que se delibera, nessa reunião secreta de São Paulo, sobre um 'levante do campo', que estaria programado para o próximo dia 10 (...)”
}

Qual a revista Veja, o sujeito do discurso do jornal O Estado de S.Paulo identifica-se com a mesma FD já analisada anteriormente. Verifica-se aqui a mesma tentativa de criminalizar o movimento, ainda que agora existam outros significantes. O que mais chama a atenção é a rede encadeada pelos indícios "clandestinamente, segredo, encontro secreto"; todos eles significam o perigo / a ameaça de uma organização subterrânea e oculta, que não se mostra inteiramente. Uma espécie de Serviço Secreto bondiano às avessas, pois, ao invés de estar a serviço de Sua Majestade, como 007, coloca-se contra o poder instituído e pretende reformar a ordem vigente e estabilizada pela formação ideológica dominante.

Sociedade secreta sempre esteve associada a uma atividade restrita a poucos, sem finalidade coletiva ou compromissada com o coletivo. Estrutura cujos objetivos são conhecidos apenas por seus integrantes e não podem ser partilhados às claras. Dentro do mecanismo promovido pela ideologia, o lugar discursivo e simbólico, em que os sem-terra são colocados, pode ser definido com algo restrito a um "grupelho" ou a "meia dúzia de gatos pingados" conforme já interpretei anteriormente. 
TFOUNI E ROMÃO - O MST no discurso jornalístico:

$\mathrm{O}$ mesmo efeito de sentido se concretiza aqui, promovendo re-atualizações e retomadas, consolidando a imagem negativa do MST. Além disso, o sujeito edifica a noção de marginalidade (e até mesmo ilegalidade), posto que muitas organizações secretas têm seus objetivos e integrantes anonimamente agindo de maneira escusa em atentados à ordem "democrática". Alguns grupos promovem ataques agressivos.

Continuando o jogo discursivo da memória, e o processo de sobreposição Bond/ Enéas já apontado acima, temos que no relevo lingüístico aparece a marca "peripécias". Ao usá-lo, o sujeito movimenta o efeito de sentido da brincadeira e do descompromisso como lugar representativo para fixar o outro. Ele (sem-terra organizado) se esconde, vive no círculo subterrâneo do anonimato e "prega peças" nos outros, zomba da realidade, aventura-se a chacotear a democracia em poucas regiões do país. Ou ainda arvora-se em D. Quixote ridículo, realizando feitos que não passam de pequenos acontecimentos, mas supondo que sejam heróicos e grandiosos. A demarcação aparentemente aleatória de "cinco regiões" nas quais o MST atuaria ("Pernambuco, Mato Grosso do Sul, Rio Grande do Sul, Paraná e Pará") produz o efeito de que existiriam sem-terra e lideranças reunidas apenas nos estados citados. Silencia-se (apaga-se), desse modo, a dimensão nacional do MST. Nega-se o caráter reivindicativo dos diretórios espalhados por todo o país. A ideologia dominante promove o enfraquecimento da luta pela terra minguando-a mais uma vez, conforme ela fez o discurso funcionar na FD dominante nos acontecimento de Ibicaba e Canudos. (Ver, também, Romão, 2002)

Retornamos à reportagem da revista Veja e detemo-nos a observar a fotomontagem, que acompanhou o texto. Percebemos que o efeito de sentido produzido naturaliza o Movimento como criminoso. A relação dos "feitos" realizados por Stedile, que se alinham ao lado da foto, remete ao Código Penal. Trata-se de uma espécie de "ficha corrida" lista de "crimes" previstos no Código Penal: "formação de quadrilha, violação de domicílio, furto, corrupção de menores, lesão corporal, cárcere privado, dano”. De maneira enumerativa, fácil de ser lida e compreendida, o texto funciona discursivamente como uma demonstração de que os crimes descritos unem MST e Stedile. Ao re-velar os crimes cometidos pelos militantes, o discurso silencia os crimes de que eles são vítimas. Colocandoos na posição de agentes criminosos, causas do mal, donos da agressão, apaga-se a violência que eles sofrem, encobre-se o sofrimento que lhes é impresso no cotidiano da miséria e da exclusão. AFD dominante, em sintonia com interesses dos latifundiários, veicula, no discurso da grande imprensa, a tropicalização do mal, como se ela brotasse sem reação, sem causas históricas e sem motivos econômicos ou políticos. O processo de naturalização de sentidos promovido pela ideologia dominante surge aqui com toda sua força excludente e silenciadora.

Texto e quadro da revista Veja alimentam-se mutuamente. Estreitam uma continuidade discursiva, cuja prioridade é associar MST à violência. A única diferença entre os dois dados é que, no quadro, há uma explicação mais enxuta, condensada dos "crimes cometidos". Didaticamente, o texto informa um boletim de ocorrência (B.O.) dimensiona o perigo que ronda a nação: o MST aglutina bandidos e violadores da lei sob o comando de Stedile.

Colocando-se na posição de juiz, o autor, protegido em seu anonimato pelo modo de funcionamento objetivizante e universalizante do discurso jornalístico (o que atrbui "veracidade" ao seu dizer) sentencia a solução para o caso. Longe de avaliar os fatos de 
Cadernos de Estudos Lingüísticos 46(2) - Jul./Dez. 2004

modo imparcial, o que se contorna aqui é a tentativa de fazer crer que a única medida (único sentido adequado) é a condenação da liderança. A repetição em negrito do significante "pena" endossa tal tentativa. Aprioristicamente, o autor, como porta-voz da revista, fecha o caso, encerrando qualquer perspectiva de defesa, de liberdade. Em resumo ("sumariamente"): "prisão". Sob a sombra da lei, a concepção de verdade mais uma vez é evocada. A lei está acima de qualquer autoridade: isso reluz nessa discursividade. A perspectiva da ilegalidade reforça a noção de perigo; nesse caso, perigo nacional, já que o rol de ações do MST passeia pelas propriedades públicas e particulares, "importunando a ordem nacional, atribulando a paz do cidadão de bem” e, por assim dizer, afetando a propriedade e as classes abastadas.

Pode-se aproximar a imagem que islâmicos e sem-terra recebem do discurso jornalístico. Talhados como a imagem do diferente, como a face sombria do perigo, ambos significam o mal. Como o autor Arbex (2001) coloca, o primeiro é visto como diferente, exótico, distante e fanático, ao passo que o segundo significa uma representação simbólica de atraso, pobreza, perigo, ameaça, fanatismo e criminalidade, bem próximos. Certo é que o mesmo combustível ideológico alimenta a FD, que discursiviza os vilões da atualidade, seja no plano internacional, seja no nacional. A atualização internacional desse movimento está cristalizada pelo significante "terrorista", que vem sendo usado pelo governo Bush como mote para justificar agressões e invasões a países soberanos. Não temos agora outro interesse senão o de registrar que a ideologia promove a consolidação de um sentido único, construindo identificações entre sentidos já postos e sentidos atuais, relançando a denominação negativa dos sem-terra e do MST.

Mas, se de um lado, há uma FD dominante funcionando no discurso jornalístico da maneira como apresentamos acima, de outro, há uma FD contrária e de resistência, alocada também no discurso jornalístico e materializada na revista Caros Amigos. Este novo acontecimento atualiza o conflito discursivo, que se coloca ao longe dos acontecimentos das Descobertas, Quilombos, Ibicaba, Canudos, Contestado, Ligas Camponesas, e volta a irromper no discurso da atualidade, seja nos depoimentos de sujeitos, que se colocam em posição contrária ao MST, seja nas páginas do discurso jornalístico. Tal confronto ficou materializado na publicação da entrevista com o líder do MST, João Pedro Stedile na revista Caros Amigos, número 39, ano IV de junho de 2000, a qual enfocaremos a seguir.

Uma fotografia acompanha a reportagem: sob um fundo azul-céu, a foto de Stedile tem aparência de um homem distinto, humanizado, sério. Ao invés de sacar uma pistola, como na capa da Revista Veja, o líder saca a Constituição brasileira, indicando a ferramenta legal, o dispositivo legítimo de sua luta. 


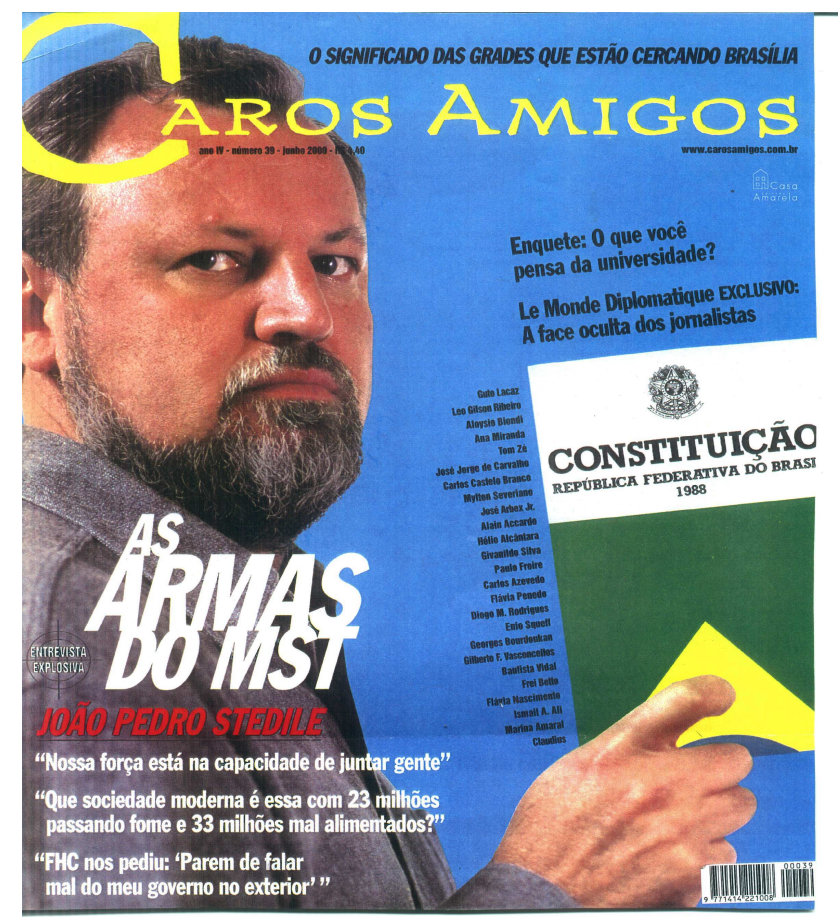

Os significantes "crime, grades" dispostos em outros recortes da capa da Revista Caros Amigos apontam a aparição de FDs antagônicas. Ao puxar o "gatilho" metafórico da Constituição, o líder aciona várias "armas do MST", como a indicar os vários instrumentos de luta e resistência do movimento. O plural acentua o efeito de sentido de que não são quaisquer armas, mas sim as usadas pelos integrantes e líderes do Movimento. O valor simbólico e a materialidade lingüística do discurso da capa é o que iremos interpretar a partir de agora.

Em sintonia com as cores da bandeira verde-amarela-azul-branca, sinal de luta pela pátria de tantos brasileiros excluídos, o sujeito Stedile tem seu discurso direto apresentado em pequenos recortes logo na capa da revista. A foto, as cores e o texto conformam o rosto de uma FD em que o sujeito ocupa a posição de reivindicação, aglutinado em torno da ocupação de terra. Entendendo que um sentido começa a se conformar na musculatura da língua, a razão de ser das ocupações está vinculada à luta pela terra, ao trabalho braçal e à representação que ele expressa. Só assim, é possível arrebentar a distância enorme entre a casa-grande e a senzala, entre a nobreza e a plebe, entre a fartura e a fome e, sobretudo, entre os que têm endereço fixo e os que migram, deserdados. O sujeito enuncia do lugar social em que circulam tais sentidos. Vemos aqui que a voz genérica do jornalista é apagada e substituída pelo discurso do próprio personagem da matéria da capa, o que produz o efeito de verossimilhança e fidedignidade dos sentidos veiculados por Stedile. (Cf. Romão, 2002). 
Cadernos de Estudos Lingüísticos 46(2) - Jul./Dez. 2004

Por outro lado, o uso do "nós" entendido como inclusivo ("nossa força, nos") evoca uma coletividade, uma representação impessoal que, atribuindo união a um conjunto, identifica diferentes em torno do mesmo discurso. Não se trata de um violino tocando solitariamente uma sonata, o discurso do nós monumentaliza uma avalanche de violinos sob a mesma nota musical. O efeito de sentido de "nossa força" na capa de uma revista advém da polifonia: o locutor pode ser tanto Stedile quanto a própria revista, um coletivo anônimo, porém poderoso, porque é a mídia. Fontana (1997, p.80/102) investigou o elo que o "nós" costura no discurso alfonsinista. Assegura a autora que:

"Obtemos um nós = sujeito universal de direito que funciona discursivamente como categoria
conceptual homogênea, que não permite operações de divisão interna pelas quais os elementos
que integram sua extensão poderiam ser distribuídos em conjuntos discretos: o eu e o tu/vocês(s),
ele(s) da relação de interlocução(....) Dessa maneira instaura-se como referente discursivo da
forma do NÓS inclusivo a representação de um todos coletivo, uniforme e totalizante(...)”

Ao contrário da indeterminação usada no discurso conformado à ideologia dominante, usado pela revista Veja, que produz um efeito de afastamento entre enunciado e enunciador, garantindo a tão propalada objetividade dos fatos, temos aqui um uso inclusivo do indeterminador: "nós" representando "todos" os que escrevem (falam) e os que lêem (ouvem). Uma universalidade que inclui, que promove uma abertura para a seqüência metafórica de significantes que se alinha como "armas" do Movimento.

A “capacidade de juntar gente” indica um movimento em direção ao “nós”: Sozinhos, os sem-terra não conseguem visibilidade no cenário nacional. Cada trabalhador rural (migrante, andarilho, pobre) isolado - seja na cidade ou no campo- mina a explosão performativa da FD de luta pela distribuição da terra. O "cada um por si" arquiteta um olhar desviante, que atribui culpa ou desempenho a uma pessoa em particular, desvencilhando-a de um contexto sócio-histórico. Daí FDs que anotam o trabalhador da roça como analfabeto, incapaz, preguiçoso, limitado, sem conhecimentos das parafernálias do mundo mecanizado da agricultura. Um pobre coitado, "iletrado", com toda as sua carga ideológica negativa cuja única alternativa é trabalhar como bóia-fria desde o nascimento até a morte. No berço do podão e na cova da enxada: como dizia o poeta, um cadáver que anda...

Ainda sobre a FD a que se alinha o discurso da Revista Caros Amigos, é possível inferir que os crivos de denúncia do sujeito orbitam em torno das condições de produção desses efeitos de sentido. Enumeramos algumas marcas lingüísticas desse processo: "23 milhões passando fome" $e$ "33 milhões mal alimentados". Tais recortes propõem um problema de relevância no país: a fome. O uso das estatísticas cria um efeito de realidade e verdade, capaz de ampliar a dimensão do problema: não são poucos brasileiros, são milhões de seres afetados pela falta de alimento. Ao ressaltar a quantidade, o sujeito discursiviza a injustiça, a exclusão social no que diz respeito ao item básico da sobrevivência humana: a alimentação.

Por não ser uma luta individual, o sujeito enuncia números, que fortalecem o tamanho da base da pirâmide social: milhões. A matemática permite observar uma noção de credibilidade evocada para que o sentido seja: há muita gente fora das mínimas condições de sobrevivência; estatisticamente isso é inquestionável, visto que se manifesta como tradição de uma realidade quantificável. O discurso constrói o sentido de que não há 
TFOUNI E ROMÃO - O MST no discurso jornalístico:

modernidade (nem pós-modernidade) quando seres humanos reviram latas de lixo para encontrar "detritos" para comer, quando o susto do poeta Bandeira ainda pode ser ouvido nas cidades: "O bicho, Meu Deus, era um homem". E, também, quando a voz grave de João Cabral sussura que "de fome se morre um pouco por dia" na condição de tantos severinos no campo. Ao puxar a discussão da fome, o sujeito-líder arrasta a atenção do leitor para um problema social gritante, para uma imagem que não aparece nos cartões postais, nas novelas da Rede Globo nem nas páginas das revistas coloridamente esculpidas. Enfronha-se, assim, nos bueiros da miséria social para arrancar deles os cidadãos afogados na fome e alimentados pelo beco e manifestar o seu grito da reivindicação radical e legítima.

\section{IV- CONCLUSÃO}

A discussão em torno do discurso jornalístico abre nova versão do conflito entre FDS antagônicas. Quando a pauta é terra, o sujeito se inscreve em determinada região de sentido para enunciar, predominantemente, a FD dominante, mas também a favor ou para contestála, na FD de resistência. De um lado, o sentido dominante sustenta os relatos jornalísticos legitimados nas redações, em consonância com o poder, o dizer e o saber; de outro, relatos que visam desconstruir os sentidos dominantes instalam uma outra ordem de discurso e um acontecimento, aquele que insere a justiça social no cerne da narrativa jornalística.

A FD dominante circula na grande imprensa- grandes jornais e revistas 'conceituadas' - sempre promovendo a satanização dos sem-terra, expulsando e negando a sua condição reivindicatória. A criminalização dos líderes faz parte do jogo discursivo promovido pela ideologia, tropicalizando a marginalidade em dose dupla: além de serem expulsos da terra e das mínimas condições de vida - marginais, portanto- os sem-terra e o MST são expulsos da legalidade, o que os virtualiza como o grande Mal da atualidade brasileira. Vale lembrar que esse movimento de sentidos é afetado pela memória discursiva, conforme já foi analisado em conceitos e interpretações anteriores. Os acontecimentos históricos das Descobertas, Quilombos, Ibicada, Canudos, Contestado e Ligas Camponesas conservam a memória discursiva e apontam o mesmo funcionamento ideológico, além de recolocarem o conflito como uma grande performance discursiva nacional.

Contra essa FD dominante, como já dissemos, há um movimento de resistência do sujeito na posição de sem-terra. A necessidade urgente de buscar alternativas de sobrevivência, a convivência diária com a fome e a exclusão social assim como a dificuldade de interlocução com os líderes políticos fixados no governo temperam os sentidos de indignação, revolta e mobilização social. O imperativo na construção de um "nós" forte e inclusivo potencializa o discurso de luta pela terra e pela cidadania.

Deste modo, concluimos que, apesar de o discurso jornalístico, enquanto tipo, adotar estratégias retóricas como a da apresentação dos fatos como sendo verdades objetivas, o que se concretiza pela utilização de marcas formais bastante definidas tais como a indeterminação do sujeito do enunciado ou o apagamento do nome do autor, vemos que existe uma heterogeneidade, produzida pelas condições materiais das classes sociais antagônicas, e esta heterogeneidade retorna na forma de uma FD de confronto, de resistência. Assim, os mesmos recursos lingüísticos servem a acontecimentos diversos e costuram em lugares diferentes o tecido social. 
A voz abafada e negada historicamente não se cala, já que a memória discursiva também mobiliza o canto da semeadura nos ditos dos camponeses ao longo das lutas messiânicas e políticas desde o século passado. Hoje, há sujeitos buscando significar a sua prática como legítima, no plano político, e legal, no plano jurídico; rasgando a FD dominante e teimando em fazer circular sentidos de justiça. Assim, o que se observa na atualidade e na mídia impressa é o discurso do conflito.

\section{REFERÊNCIAS BIBLIOGRÁFICAS}

ACHARD, Pierre. (1999). Memória e produção discursiva do sentido. Em Papel da memória, pp. 11-17) Campinas: Pontes.

ARBEX JUNIOR, José. (2000). Questão de consciência. Em Revista Caros Amigos, nº 45. São Paulo: Editora Casa Amarela.

. (2001). Showrnalismo, a notícia como espetáculo. São Paulo: Casa Amarela.

CERTEAU, Michel de. (1999). A invenção do cotidiano. Petrópolis: Editora Vozes.

FONTANA, Mónica Zoppi. (1997). Cidadãos modernos- discurso e representação política, Campinas: Editora da Unicamp.

FURTADO, Thaís Helena. ( 2000). As lacunas de sentido no discurso jornalístico: do repórter ao editor da Revista Veja. Porto Alegre: Universidade Federal do Rio Grande do Sul. 132p. (Dissertação de Mestrado).

GUIMARÃES, Eduardo. (2002). Semântica do acontecimento. Campinas: Pontes.

MARIANI, Bethania. (1998). O PCB e a imprensa. Campinas: Editora da Unicamp e Editora Revan.

PÊCHEUX, Michel. (1975). Semântica e discurso- uma crítica à afirmação do óbvio, Campinas: Editora da Unicamp.

ROMÃO, Lucília Maria Sousa \& TFOUNI, Leda Verdiani. (2002). Vejam, caros amigos: o lítígio discursivo. Revista Eletrônica de Ciência Política ACHEGAS, nº 2. (www. achegas.net), 2002.

ROMÃO, Lucília Maria Sousa. (2002). O litígio discursivo materializado no MST: A ferida aberta na nação. Ribeirão Preto: Faculdade de Filosofia, Ciências e Letras da Universidade de São Paulo, 2002. 310p. (Tese, doutorado em Psicologia).

SILVA, Carlos E. L. da. (1988). Mil dias- os bastidores de uma revolução em um grande jornal. São Paulo: Trajetória Cultural.

TFOUNI, L. V. (2002). Letramento e atividade discursiva. In: Tfouni, L.V. Alfabetização e Letramento. São Paulo: Cortez Editora, cap.4, pp. 64-85.

TFOUNI, Leda Verdiani \& ROMÃO, Lucília Maria Sousa. (2002) O discurso sobre Canudos e a retórica do massacre. Revista Terra Livre $\mathrm{n}^{\circ} 19$.

VOESE, Ingo. (1998). O Movimento dos sem-terra na imprensa: um exercício de análise de discurso. Ijui: Editora Unijui. 